\title{
Against "the European Notion of Man": Levinas, Freedom, and the Responsible Body KaTHY KILOH
}

Running throughout Emmanuel Levinas' oeuvre is a conception of corporeality, embodiment, or what might be better described as "the experience of our bodies" ("Reflections" 7) that rejects the abstract separation of body and spirit marking the Western philosophical tradition. A conception of the adherence of the self to the body is crucial to Levinas' understanding of the ethical relation between me and all the others because it locates both my freedom and my responsibility for the other in the inseparable unity of body and spirit. In fact, to speak in this way of a unity of two separate entities is to get it wrong, to speak in the language of a philosophy that misunderstands the cognitive and ethical status of the corporeal.

Levinas' early essay "Reflections on the Philosophy of Hitlerism" provides us with a clear description of just what it is that his conception of subjectivity as a lived, bodily experience rejects: "the European notion of man" (7). Levinas shares this position with the school of thought that he identifies as the philosophy of Hitlerism. "Reflections on the Philosophy of Hitlerism" is a remarkably daring - even shocking - essay in that it recognizes the folly of attempting to save liberal conceptions of freedom and dignity from a thought that takes the adherence of the self to the body seriously. ${ }^{2}$ Levinas certainly rejects the racist conclusions reached by the

\footnotetext{
${ }^{1}$ This point is already suggested in Asher and Gad Horowitz they point out that Levinas' desire for "a definitive break with the Western tradition culminating in liberalism" is found in the German refusal to separate body and soul (16). This point is also noted by Manning 126.

${ }^{2}$ Nonetheless, much of the secondary literature ignores or downplays this critique of liberalism. Annabel Herzog makes Levinas into an advocate of private charity within a liberal state and Fred C. Alford's claim that Levinas presents an "inverted liberalism" assume that liberalism is, in fact sufficient - that we've simply taken a wrong turn somewhere, that what Levinas calls for is a correction to bring us back to an ethical and functioning liberalism for the other. This position ignores the fact that Levinas takes issue with the roots of liberal thought, represented by Thomas Hobbes, throughout Totality and Infinity, and that he levels a firm critique in "Reflections on the Philosophy of Hitlerism" against the foundations of liberal thought. Both Herzog's and Alford's account of Levinasian subjectivity are oddly devoid of the painful and traumatic nature of this "for the other" that appears in later essays and Otherwise than Being or Beyond Essence as
} 
philosophy of Hitlerism, ${ }^{3}$ but he also recognizes the fundamental truth underlying its presentation of the spirit as enchained to the body: that both material and spiritual needs lie at the very foundation of our subjectivity. Reading "Reflections on the Philosophy of Hitlerism," one is left with the impression that Levinas devoted his life's work to the task he sets himself in this essay - to conceive of humanity in a mode that is entirely beyond the "European notion of man" (7) - and that to do so, one must begin with the experience of our bodies. It is, first of all, crucial for us to understand what it is that Levinas means by the phrase "European notion of man." Secondly, we must consider whether or not his philosophy accomplishes this task.

In what follows, I will trace the argument Levinas presents in "Reflections on the Philosophy of Hitlerism," providing links between this early essay and Levinas' later, major works: Totality and Infinity and Otherwise than Being or Beyond Essence. By orienting the later works towards "Reflections on the Philosophy of Hitlerism," I will reveal that at the heart of Levinas' depiction of the subject as creaturely and his discussion of subjectivity as substitution lies a political interrogation of the liberal tradition. Integral to Levinas' conception of subjectivity is his deep understanding of "the experience of our bodies" ("Reflections" 7) and what this experience reveals about individual freedom and the asymmetrical responsibility engendered in the ethical relation. ${ }^{4}$ As creatures, and as subjects in substitution, we experience our own freedom as dependent upon our responsibility for the others; the Levinasian subject cannot conform to the racist ideology promoted by the philosophy of Hiterlism without renouncing her own freedom.

In "Reflections on the Philosophy of Hitlerism," Levinas writes that the "elementary feelings" awakened by Hitlerism "harbor a

substitution: the breakup of identity. In their accounts, Levinas' "correction" of liberalism requires rather little of the subject. Neither take account of the radical nature of Levinas' critique of the liberal tradition and even Marx's economic and political theory. Consequently, neither address Levinas' insistence that the materiality of the body must enter into all our social and political deliberations.

${ }^{3}$ Gad and Asher Horowitz (13) argue persuasively that this phrase refers not to National Socialist ideology alone, nor to the work of a specific philosopher, but rather to the school of thought associated with German conservatism in the early $20^{\text {th }}$-century.

${ }^{4}$ In this, I follow Chanter who characterizes her own interest in "Reflections on the Philosophy of Hitlerism" as an attempt to "gain an insight" into the source of Levinas' thought "by laying bare the "original decision" that set Levinas' thinking in motion" (142). While Chanter's essay is important and formative to my own perspective on this early essay of Levinas', my reading does differ from hers in one important respect. Chanter, as does Manning, reads Levinas as approving of the liberal ideal of a "community of masters" (142) created in universality. I will take the position that it is this desire for mastery that links Western (Christian, liberal) philosophy to the domination inherent in the force of expansion utilized by the philosophy of Hitlerism. 
philosophy [and] ...they express a soul's principal attitude towards the whole of reality and its own destiny" (4). These feelings are elementary in the sense that they are the basic feelings associated with embodiment, material need and dependence that the "European notion of man" (7) represses. The philosophy of Hitlerism surpasses the ideology propagated by Hitler and his supporters, extending to the point of "question[ing] the very principles of a civilization" (4); it reveals that the principles of Western civilization are built upon an armature made unsteady by the repression of its own material foundations. Writing in 1934, Levinas noted that we must not only understand where this philosophy of Hitlerism comes from in order to challenge Nazism, but we must also take up the critique of European civilization that this philosophy presents. In the preface to "Reflections," written in 1990 with the gift of hindsight and with a look to the future, Levinas suggests that the essay asks "if liberalism is all we need to achieve an authentic dignity for the human subject" (3).

Levinas neglects to define what he means by "liberalism" in the preface, but in the essay itself, he draws our attention to the foundations of liberal rights discourse laid out by the $18^{\text {th }}$ century French writers who recognized reason as the sovereign triumph of the mind over material necessity. The expressed goal of this domination of the material is freedom from necessity that opens onto freedom from history. The liberal subject is thus free to determine her own destiny; this power of selfdetermination ensures that she is in possession of dignity. Because this conception of freedom is predicated upon an abstracting discourse of natural or divine rights universally possessed by humanity, the liberal subject purchases absolute freedom from necessity by denying her materiality and thereby forfeiting her uniqueness.

Levinas hints at this connection between the liberal conception of freedom and the logic of universality at the beginning of "Reflections" when he notes the insufficiency of a critique of Hitlerism that proceeds by opposing Christian universalism to racist particularism. He suggests that "the meaning of a logical contradiction that opposes two forms of ideas only shows up fully if we go back to their source" (4) and this is what he, in fact, enacts in the essay: a return to the source of this logic in "the original decision" (4) that makes the linkage of universality and particularism possible. Universality, adopted by both Christianity and the liberal tradition, inflicts violence upon the particular that it assimilates. Repeating the Ancient Greek conception of being as the unity of the many in the One, liberalism, out of a fear of the heterogeneity that the other represents, seeks to bring alterity back into the fold, as Victoria Tahmesebi-Birgani has it, through acts of benevolence (7). This continuation of pagan logic within liberalism makes possible the 
reformulation, within the philosophy of Hitlerism, of universality as expansionism.

Levinas finds that neither the Christian tradition nor secularized liberalism has freed itself of this elemental urge: the regressive desire for a homogenous unification of differentiated being in the One. In "Reflections on the Philosophy of Hitlerism," Levinas takes aim at the pagan logic that characterizes the "European notion of Man;" the source of this logic is identified in the ancient Greek tradition that precedes and informs Plato's idealism, in which imperfect nature is figured as derivations of the One (in the form of the Platonic idea). But, as he is keen to show, this logic pervades modern society as well. If we are to stamp out what he refers to as paganism (the regression of the differentiated many into a unification with the One in which individual responsibility devolves into participation), Levinas suggests that we must return to an originating monotheism to uncover what was lost in the development of Christianity and, later, liberalism.

Levinas celebrates the liberal tradition for its attempts to enshrine dignity and freedom as basic human rights, but he also accuses liberalism of failing in its task of guaranteeing individual dignity. Dignity, for Levinas and for liberalism, would be the subject's freedom from coercion and objectification; as Kant has it, dignity is conferred upon that which has no price within the marketplace (Kant 96-97). In other words, dignity is attained in the subject's freedom from determination by forces beyond its control, whether these forces are identified as the elemental evil of the pagan unification of the many in the One or as subjection to the logic of the capitalist economy. Levinas notes that within the liberal tradition, the dignity of the individual is defended with reference to its possession of divine or natural rights, or its possession of universal reason. In both cases, that which guarantees the subject's freedom from objectification and coercion proceeds by way of objectification and coercion. Rights and reason, intended to serve as the bedrock for human dignity, are made into objects capable of being possessed. Furthermore, both rights and reason are universally possessed by human beings; this logic mirrors the pagan unification of the many in the One because within the Kantian moral system, all morally correct individual thought and action must conform to the general principles of a universal reason. So Levinas concludes that the dignity that liberalism claims to guarantee the human subject is the decidedly inauthentic dignity of sovereign reason; liberal "freedom" exists as conformity.

Levinas blames this failure to protect humanity from the logic of the many in the One on liberalism's blindness; liberalism is blind to the danger inherent in its repression and devaluation of the bodily in favour of an abstract reason that has not freed itself from this logic. In rejecting the body, liberalism has denied itself resources that could assist philosophy in 
a reorganization of its own faculties that might allow it to resist and transcend the logic of the many in the One. Liberalism promulgates a dominating subject that declares itself to be free of necessity on the basis of force, will, action, and an autonomy paradoxically achieved through its own alienation.

Precisely that which is deemed exterior or inferior to reason returns in the form of a philosophical critique of the Enlightenment that Levinas dubs the philosophy of Hitlerism. The philosophy of Hitlerism reintroduces into thought an explicit engagement with the pagan conception of embodiment. Levinas sees this as an important move, because it highlights the Enlightenment's inability to cleanse culture of this logic through the process of disenchantment. Levinas notes that we must heed the demands of the philosophy of Hiterlism: to re-incorporate the material body into our thinking. But for Levinas, the key to this reincorporation is to uncover a relation between body and spirit, the physical and the abstract that removes us from the plot of the many in the One, securing human dignity and freedom through our embodied responsibility for the other.

\section{Pardon: The Very Work of Time}

According to the European notion of man, the self is determined to be free based on its possession of natural rights. Social bonds come to restrict that freedom only after the individual has elected autonomously to transfer these rights in order to unite herself with others through entry into a social contract. ${ }^{5}$ The absolute freedom associated with life in a state of nature is traded in for a conception of freedom as liberty within social bounds. Within social contract theory, freedom is conceived of as freedom from the natural conditions of humanity. The autonomy of the self is predicated upon a repression of the natural and the bodily. In this sacrifice of individual rights and freedoms to membership within a social and political group, we see a repetition of the pagan logic of the many in the

\footnotetext{
${ }^{5}$ Social contract theory begins, of course, with Hobbes's theory of the Leviathan, and receives fine-tuning in the philosophies of Locke and Kant. It reaches its penultimate moment with Rousseau, whose work can be seen as a critique and a reformation of the earlier social contract theorists. Rousseau famously chided social contract theorists for their depiction of man in a state of nature, arguing that their states of nature included far too much culture. Levinas' description of "the European notion of man" seems much closer to Hobbes than any other social contract philosopher, in that Hobbes conceives of human beings as primarily atomistic, and engaged in a struggle for power within a closed mechanical social system. The sense of a "European notion of man," to which Levinas' opposes subjectivity as substitution, would thus be atomistic, self-interested, selfpreserving, in a proprietary relation to itself, and locked into mechanical relations with other human beings, bounded by a finite and totalizing power structure.
} 
One. In "Reflections on the Philosophy of Hitlerism," Levinas traces the liberal claim for the autonomy of the self historically, arguing that it develops out of the idea of the soul in monotheistic thought that is itself a reaction to the way in which history and time are conceived as fate and destiny within the pagan world. In the progressively abstract development from Christian soul to liberal self, an important linkage between embodiment and individual freedom is denied, and this denial facilitates the liberal subject's sacrifice of its own potential dignity when entering into the social contract.

According to the pagan worldview, we are fundamentally bound to a past that cannot be sufficiently altered in the present. For the pagan, every act performed fails to achieve the status of an original act; within the passage of time, human action is doomed to be a mere continuation of immanent existence, an eternal submission to fate. The pagan conceives his or her life as predetermined by fate, while, within the liberal tradition, it is posited that the autonomous individual, freed from the unchanging past, controls her own destiny, thereby securing her individual dignity. The sovereignty of reason surpasses the freedom offered by the Christian notion of the soul in that decisions made about one's present and future acts need not concern history, necessity, the will of God, nor even a relationship to one's fellows; the only basis for decision is decidedly abstract Enlightenment rationality. Through the sovereignty of reason, the human being is absolutely freed of all material concerns, and even of psychological need; faith in reason, Levinas writes, possesses a mystical power that "exorcises physical, psychological, and social matter. The light of reason was enough to chase away the shadows of irrationality" ("Reflections" 6). The liberal subject is constituted as an immaterial entity entirely devoid of corporeal concerns such as hunger and scarcity- the very material concerns that force us to make decisions about whether we behave in an ethical or an evil manner towards our fellow human beings. For the liberal subject, these moral and ethical decisions can only be determined as objectively rational or irrational; all moral decisions take on the character of rational calculation. The members of this rational community are treated as abstract entities; in their distance from the material world, and hence, one another, liberal subjects become "a community of masters" (11): equivalent to one another, and thereby interchangeable.

In light of this, Levinas suggests that true freedom-a break with the subject's submission to fate, whether we speak of this as a characteristic of life in the ancient or the modern world-requires a "true present" (4-5): a moment in time in which destiny is interrupted and begun again. In this true present, the passage of time is reversible, and the human being stands at the crossroads of the two directions in which time travels. Levinas identifies the promise of this reversibility of time (the promise of 
a true present) with the Judaic promise of redemption, and implies that in the development of Christian and liberal thought this true redemption is replaced by a faith in abstraction that returns us to the plot of the pagan. He explains that with the arrival of monotheism (in the form of Judaism), ${ }^{6}$ "remorse - the painful expression of a radical powerlessness to redeem the irreparable-heralds the repentance that generates the pardon that redeems. Man finds something in the present with which he can modify or efface the past. Time loses its very irreversibility" (5). However, Levinas does not clearly specify from where this remorse arises is in this early essay.

Time becomes reversible when man learns to repent past actions. Levinas implies in "Reflections on the Philosophy of Hitlerism" that this specifically Judaic ability to modify the past through pardon makes possible the Christian notion of the separated soul as well as the liberal conception of the subject as wholly self-sufficient. However, the independence and atomism we see developing out of the Christian tradition are not characteristic of Levinas' conception of Judaism. While the Jew labours in repentance, the Christian is delivered the true present and freedom from mythic fate through his or her faith in the crucifixion and the Eucharist. The Christian is reborn into freedom from the past, free to choose his or her destiny. So for Levinas, Christianity heralds a radical freedom; he writes: "not only is the choice of destiny a free one. Once the choice is made, it does not form a chain" (5). Every choice, commitment, and repentance is itself open to reconsideration and modification. In this sense, the past is subordinate to the present, and the Christian has no history that could limit her freedom. A slogan displayed on the marquee sign of an evangelical church demonstrates this point of view: "God allows u-turns." The spontaneous, originating, and infinite freedom that

\footnotetext{
${ }^{6}$ Levinas limits his discussion of "monotheism" in "Reflections on the Philosophy of Hitlerism" to only two of the religions of the Book: Judaism and Christianity. The essay under review here, written for a Catholic journal (L'Esprit), addresses, in part, the potential (or lack thereof) resources within Christian thought for mounting a resistance to the philosophy of Hitlerism and Nazi ideology. It is likely that the specific audience to which the essay is addressed accounts for its engagement with certain aspects of monotheism at the expense of others. Nonetheless, it is undeniable that Levinas' philosophy emerges out of an idiosyncratic reading of Judaism that attempts to rescue and mobilize the originating anti-pagan impulse motivating Judaism itself. Christianity appears in his work, as it does here, as an outgrowth of Judaism that incorporates the pagan Greek tradition into its theology and philosophy. Hence, Judaism is treated as the non-European monotheistic tradition that contains the resources necessary to counter the pagan logic of the many in the One. Islam, of course, receives short shrift from Levinas here, as it does throughout his work. It is quite clear that for Levinas "monotheism" refers to its original manifestation within Judaism. Christianity and Islam, according to Levinas, stray too far from the aim of the originating monotheism: to rid the chosen people of their pagan beliefs and practices.
} 
Christianity makes possible animates the Christian notion of the soul. Levinas argues that the Christian soul is not an abstraction; it is, he writes, "the concrete and positive power to become detached and abstract" (6). The past is no longer a limitation upon human freedom, because the Christian soul provides mankind with the mechanism through which one escapes the past by detaching oneself from it.

Classical liberalism, Christianity and Judaism share the desire to be freed from the limitations of the time of being, which, conforming to pagan fate and the logic of the many in the One, is determined as a synthetic totality demanding conformity to the same. But unlike the JudeoChristian conception of freedom, liberalism guarantees this flight from history and necessity as an absolute freedom. The sovereignty of reason operates outside and above everyday concrete existence, because, according to Enlightenment thought, what is truly human transcends community with other human beings or obedience to God-the social and religious structure that both makes freedom possible in the JudeoChristian world and simultaneously limits and qualifies the freedom it provides. This becomes especially problematic when considered in light of the argument presented above: that in liberating itself from material necessity, Enlightenment does not free itself from pagan logic, but in fact, further entrenches itself within the plot of the pagan by blocking a potential egress from this logic when it turns away from the concrete body and towards abstraction. The philosophy of Hitlerism returns to a pagan conception of the concretion of the soul within the body; this allows Levinas the opportunity to identify this potential exit point.

Although Levinas does not identify the origin of the remorse that redeems in "Reflections on the Philosophy of Hitlerism," when he returns to the "true present" (4-5) that makes possible redemption and pardon in Totality and Infinity, Levinas introduces fecundity as the relation to the other that opens infinite time. Fecundity is a relationship with an other beyond the progressive temporality of history. ${ }^{7}$ The biological origins of the concept of fecundity - its very concreteness as a description of the relation between the I and the being that the I engenders (the father and the son $)^{8}$ - means that the production of this relation that opens upon infinite

\footnotetext{
${ }^{7}$ For Levinas, the term "history" in Totality and Infinity refers to the totalized, universal history we most readily associate with Hegel. The relation of fecundity is also beyond politics, or at least, politics as Levinas defines the term in Totality and Infinity: "the art of foreseeing war and of winning it by every means" (21).

${ }^{8}$ Levinas' language here is infamously gender-specific. The subject is always masculine, the child is always the son and the production of the son requires an erotic relation with the feminine. This gendered language runs through the entirety of Totality and Infinity, but it is especially present in other sections on dwelling and language, into which the subject must be welcomed by the feminine. For the purposes of this discussion, I will take Levinas at his word when he intimates that the feminine aspect of being that he
} 
time ${ }^{9}$ is created and experienced within the finite time of history itself. But as it enters into the said (the language of being), this relation loses its openness to the other, as it is transformed into a means, subsumed into the totalizing rationality of being. Fecundity is thus a relation with an other that defies the laws of formal logic; it is complicit with the totalizing logic of the totality, but it is also a site of resistance to it. It establishes identity itself as multiple in that the subject sees herself (and not merely her reflection) in the gestures and characteristics of the child; the child is "mine in a certain sense or, more exactly, me, but not myself" (Totality and Infinity 271). Fecundity "articulates the time of the absolutely other, an alteration of the very substance of him who can-his transsubstantiation" (268-269). The very identity of the subject we associate with power, agency and possibility is altered in fecundity.

The discontinuous and infinite time of fecundity, according to Levinas, is a break-up of the progressive march of time, and it "makes possible an absolute youth and recommencement" (282). This recommencement is not a reversion to the self-sufficient subject that is identical to itself; it is rather a recommencement of youthfulness as a mode of being and experiencing that is not conditioned by the synthesis of events dominating the totality. In fecundity, the past is not recommenced through memory, which subjects the past to a finite narrative leading always to the present moment of the aging subject. Rather, fecundity makes possible a return to the past that is free of the synthetic time of

refers to in Totality and Infinity does not refer to an empirical female being. He announces there that "the feminine has been encountered in this analysis as one of the cardinal points of the horizon in which the inner life takes place-and the empirical absence of the human being of "feminine sex" in a dwelling nowise affects the dimension of femininity which remains open there, as the very welcome of the dwelling" (158). In "The Delightful Other: Portraits of the Feminine in Kierkegaard, Nietzsche, and Levinas," Sonia Sikka takes issue with this, on the grounds that the feminine, for Levinas, constitutes a "break" in the "virile" identity of the masculine. From my perspective this is only a problem if "the feminine" is conflated with concrete females. One hopes that the subject does not have to identify as male. For it seems to me that the form of subjectivity that Levinas refers to using masculine pronouns could just as easily, and perhaps more precisely as well, be labeled the self-identical dominating liberal subject (which has historically been the domain most closely associated with men and patriarchal culture and social structure within the modern period). No doubt this nomenclature is, although potentially more precise, also a bit of a mouthful. Nonetheless, this subject's counterpart, who introduces difference and enters into an erotic relation that results in the transsubstantiation of the liberal subject in the relation of fecundity, would therefore be feminine only in that it would be everything that the masculine, dominating, self-identical subject of liberalism is not. It would be an interruption of masculine virility, but this is not, in itself, a bad thing.

${ }^{9}$ Fecundity is, therefore, in excess of universal history and the totalized politics of opposition. 
history and therefore allows "free interpretation and free choice" (282). The freedom referred to here is a freedom from the pagan logic characterized by a repetition of the same, since, in fecundity, the relation between past, present, and future no longer has the totalizing characteristic of the inevitable playing out of fate, an inevitable unification of the many in the One. "This recommencement of the instant, this triumph of the time of fecundity over the becoming of the mortal and aging being," according to Levinas, "is a pardon, the very work of time" (282).

Pardon is the very work of time because pardon can only be given from the perspective of a looking back, and because it institutes a relation to the passage of time that is transcendent of the totalizing progressive time that Levinas takes to be the time of being. The event to be pardoned must have occurred in the past, but the ability to pardon the offence requires the reversibility of time that the "true present" ("Reflections" 4-5) and fecundity accomplishes. Levinas explains that "the paradox of pardon lies in its retroaction; from the point of view of common time it represents an inversion of the natural order of things, the reversibility of time" (Totality and Infinity 283). To pardon is neither to forget, nor to remember the offence that occurred in the past. Forgetting it would be to move on from the event without responsibility taken or forgiveness granted, while memory would thematize the event in the unfolding of synthetic, finite time. Forgetting erases the events of the past, while pardon "acts upon the past event, purifying it" (283). Pardon preserves and transforms the past in that the offence is neither forgotten nor remembered.

To pardon is not to proclaim the innocence of the perpetrator, but rather to transform him or her from the guilty into the purified. The original event serves as the "felix culpa" (283) that brings reconciliation. This is why innocence is not to be held above pardon; it is not better to be sinless, as the state of sin that requires pardon is the very thing that opens the redemptive and ethical relation of fecundity. There can be no transformative redemption of the subject without a prior fault requiring redress. The future "comes to me across an absolute interval whose other shore the Other absolutely other-though he may be my son-is alone capable of marking, and of connecting with the past" (283). Pardon itself is not within my own grasp; it can only emerge from the other, and the pardon granted by the son offers to me my future. This future is not infinitely open, but neither is it determined by the endless repetition of events in the pagan sense of time as a totality. It is determined in and as the relation of fecundity in which I am I and not I, self and other.

The relation of fecundity between father and son (whether these terms are taken as description of a biological relation or a social relation) makes possible the "true present" ("Reflections" 4-5) that Levinas links to Judaism and the promise of redemption in "Reflections on the Philosophy of Hitlerism." In the earlier essay remorse for past actions "heralds the 
repentance that generates the pardon that redeems" (5). In Totality and Infinity, Levinas explicitly presents pardon, and the transcendence of synthetic time, oriented toward pagan destiny, that it engenders, as a function of a relation. This relation has its origin in the biological, but unfurls within the social. So some of the puzzles that present themselves in Levinas' earlier and partial reflections on time, pardon, repentance and redemption are worked out more explicitly in the notion of fecundity in Totality and Infinity. Fecundity offers the same reversibility of time, the same pardon and redemption we see in what Levinas refers to earlier as the "true present" (4-5) opened by monotheism, but, unlike the reversibility of time offered by liberalism (which requires no other to grant me pardon) it is possible only in a relation between the self and the other that opens upon the infinite, and brings infinite time into the time of history. In "Reflections on the Philosophy of Hitlerism," the "something" that man finds "in the present with which he can modify or efface the past" (5) remains poorly articulated. In Totality and Infinity, we find that this "something" (5) is the very relation between "man and man" and "the I and itself” (Totality and Infinity 306): fecundity.

\section{"The Experience of Our Bodies"}

In "Reflections on the Philosophy of Hitlerism," Levinas suggests that humanity is imperilled by liberal thought because of its adherence to the primacy of an abstractly defined freedom of rights over the call to responsibility entailed in social relations: "once the distance [between man and the world of ideas] has been crossed and the truth grasped, man nonetheless retains his freedom. Man can regain control and go back on his choice. ... This freedom constitutes the whole of thought's dignity, but it also harbours its danger. ... Thought becomes a game." ("Reflections" 10) According to the liberal tradition, the dignity of thought lies in its absolute freedom from determination-even to the point that the individual retains her freedom in the face of a truth grasped. When thought becomes a game, the human being is incapable of commitment. Hence, liberal philosophy, which declares (and claims to protect) the existing freedom of the subject, potentially devolves into a lack of commitment to one's own thought in favour of the status quo. The absolute freedom of sovereign reason, Levinas argues, results in a kind of relativism that (on an individual level) makes sincerity "impossible," and "puts an end to all heroism" and (in its wider social effect) produces a society that "accepts degenerate forms of the ideal" (10).

Levinas writes that "it is to a society in such a condition that the Germanic ideal of man seems to promise sincerity and authenticity" (10). The ascension of "the Germanic ideal of man" (10) means that thought can no longer be conceived as a game, because one cannot freely choose 
between rational ideas. The playful uncertainty of liberal thought is replaced with a thought of seriousness and import that has the power to affect the spiritual and material conditions of humanity. In the National Socialists' exploitation of this new conception of man, ideas are judged to be authentic - and therefore, true - if they exhibit an eternal tie to the racialized body and its mythic past.

What is at issue here in this development from the Christian conception of the concrete soul, making abstraction possible, to liberal declarations of absolute freedom, is the way in which this freedom untethers the subject from its body, and from the material world. The concrete freedom of the soul, which frees one from the unalterable circumstances of the concrete body, is transformed in liberal thought. Freed from all material concerns, the liberal subject is free also from a material referent, and this, perhaps, is its most dangerous quality. Astonishingly, Levinas suggests in "Reflections on the Philosophy of Hitlerism" that it is the philosophy of Hiterlism itself that offers a possible antidote to the dangerous liberal conception of freedom, and the European notion of man in which it participates. Undoubtedly, the specific form that this anchoring of the self to the body takes on in the philosophy of Hitlerism is completely unacceptable to Levinas. However, its core assertion - that the body and the self are inseparable-will continue to inform his entire body of work. In this early text, Levinas explicitly argues that liberalism cannot mount a defense against the philosophy of Hitlerism. This would require a philosophy that takes the philosophy of Hitlerism seriously, and begins where it begins: with the inseparability of body and self.

The feeling of identity between self and body that liberalism attempts to repress in the name of a sovereign reason is confirmed in what Levinas calls "the experience of our bodies" (7). Levinas identifies the experience of pain as an absolute limit case for this feeling of identity. In the experience of physical pain, the spirit longs to flee the body, rebel against the body and "go beyond it" (8). But, Levinas contends, it is the very impossibility of this escape that constitutes pain itself. Levinas argues that "[The] adherence [of the body] to the Self is of value in itself. It is an adherence that one does not escape and that no metaphor can confuse with the presence of an external object; it is a union that does not in any way alter the tragic character of finality." (8, emphasis in the original) Spirit finds its very identity as spirit in this rebellion against the pain of embodiment, but suppresses knowledge of this origin in its successive moves away from the material and towards abstraction. Liberalism misrecognizes the meaning of the identity of body and self; it reacts in fear, seeing this union as the force that denies human beings their dignity. In repressing this relation between the body and the self, 
liberalism erroneously bars the subject access to its potential liberation from the logic of the many in the One.

The experience of pain as a failed flight from this unity between self and body demonstrates that the body cannot be treated as an object external to the self (as it appears throughout the European philosophical tradition). The fact that the self is intractably intertwined with the body reveals the lie within liberalism's claim that a sovereign spirit can enter into equal and just relations with others based on its rationalized and abstract freedom from the material constraints of the body. Liberalism fails to deliver on its promise of freedom and equality precisely because it guarantees freedom and equality through an abstract formalism that ignores the material inequalities and differences that exist between concrete bodies.

In contrast, the feeling of identity between the self and the body forms the core of the philosophy of Hitlerism. The human being, once described as the animal capable of rising out of its animality through its development of sovereign reason, is now, within the philosophy of Hitlerism, conceived as the biological site of spirit's concretization. Not only the ethical and political nature of man, but the entirety of his existence is cemented within a biologically determined concept of being. Spirit accepts its bondage to the body, and a society is formed based upon common blood; the pagan reduction of the many to the One is transformed into a reduction of the many to the species - to the people - to the Volk. And, then, as Levinas writes, "if race does not exist, one has to invent it!" (9).

Levinas describes the difference between the liberal conception of the subject as free and the sense of bondage that defines subjectivity according to the philosophy of Hiterlism:

Man's essence no longer lies in freedom, but in a kind of bondage. To be truly oneself does not mean taking flight once more above contingent events that always remain foreign to one's freedom; on the contrary, it means becoming aware of the ineluctable original chain that is unique to our bodies, and above all, accepting this chaining. (9)

The philosophy of Hitlerism interprets this enchainment to mean that I am chained to my material body and through that material body I am chained to those who share my blood in the present, to those of similar stock who precede me, and to the future of the race to which I belong. But, for Levinas, this enchainment means something very different than what it means for the National Socialists.

The recognition that "man's essence ... lies ... in a kind of bondage" (9) between self and body furnishes the necessary insight 
informing Levinas' speculation about an otherwise than being or a beyond essence to which the experience of the body bears witness, and facilitates Levinas' critical alteration of Husserlian phenomenology. Husserl's idealist theory of subjectivity is countered by Levinas' phenomenological description of the experience of our bodies, which treats sensation and affect as pre-reflective embodied cognitions. Levinas' attunement to the experience of our bodies reveals the existence of gaps in the totality of being as constituted by the Husserlian subject. These gaps, Levinas suggests, point to a fuller sense of subjectivity, and bear witness to the otherwise than being as that which cannot enter into the totality, and that therefor, maintains the possibility of resistance to it.

Levinas chronicles the problematic nature of Husserl's phenomenological reduction in his Theory of Intuition in Husserl's Phenomenology, in which he argues that the life offered to theoretical reflection is not philosophically neutral; it is rather, as John Drabinski puts it, the "theoretical life of the subject in the natural attitude" (Theory 31). Because Husserl's method brackets existence, that which is subjected to reduction in Husserl does not include the full range of affective and prereflective experience. Levinas, according to Drabinski, notes that Husserl's reduction reveals "only the theoretical content latent in the prereflective" (31). In this, Husserl conforms to the pagan logic of the many in the One, as the transcendental subject becomes the origin from which all meaning and significance of being is derived. In contrast, the reduction as it is mobilized by Levinas is not a reduction to essence (as it is for Husserl), but a reduction beyond essence: a reduction beyond the philosophical system that takes knowledge of essence as its goal. Levinas expands that which is to be reduced from the latent constitutions of the ego to that which exceeds the theoretical perspective of the ego: the sensual and the affective. While Husserl's parenthetical reduction spiritualizes matter by reducing entities and things to their essence, Levinas' reduction is "the reduction to signification, to the one-for-theother involved in responsibility, in substitution, to the locus or non-lieu, locus and non-lieu, the utopia, of the human" (Otherwise than Being 45).

For Husserl, memory and historiography are tools of consciousness that allow for the retention of identity by transforming difference (for example, in aging) into mere modification. In this sense, consciousness is conservative, and exists on a plane bounded by recuperable time. But against Husserl, and as we have seen hints of already in our discussion of pardon, Levinas argues that sensibility itself is not bound by being or consciousness, is not identical with "a time of what can be recuperated" (34) by consciousness. Not everything sensed and sensing enters into the synthetic time in which the self-identical exhibition of being takes place. The simultaneity of both lived experience and the objective order of denomination within sensibility indicates instead, for Levinas, that time 
itself is irreducibly diachronic. And this diachrony indicates that the subject as sensibility cannot be identical with consciousness, because diachrony contains the immemorial not due to a "weakness of memory" (38), but because time cannot "assemble itself in the present" (38).

Within the time of being, organized as a totality, the subject is selfidentical; its meaning is derived from its essence. But what the experience of our bodies teaches us, is that this mode of constitutive subjectivity is predicated upon an ethical subjectivity that can be described as sensibility and as a substitution for the other, and this fundamental subjectivity is experienced beyond the time of being, as the otherwise than being. In the very moment in which I sense the other, my response, prior to her call, and prior to my conscious awareness of any intention, ethical or otherwise, on my part, is expressed in my substitution for her. For Levinas, the sensible "binds the node of incarnation into a plot larger than the apperception of the self. In this plot I am bound to others before being tied to my body" (76). Prior to my recognition of the enchainment of self and body and the attempt to escape this enchainment, I am already undeniably bound up in a relation of substitution for the other, because I exist as a sensing, feeling subject.

Levinas describes the subject in substitution as "denuded, stripped bare" (54), without the protection of ego identity or of "its solid crust" (49). The self is torn away from its own inwardness and self-same-ness as the other penetrates the unity at the very core of identity, and opens the self up to ethics. This penetration is substitution, in which I offer myself as a hostage in place of the other. But this bond does not resolve into unity with undifferentiated being in a repetition of the pagan logic of the many in the One, because when I enter into a relation of substitution for the other, I am absolved from ego-identity, without being alienated from my self. The denominations and qualities attributed to me within the totality of being are no longer of consequence, but rather than this being a negation of essence-or, rather, an experience of being alienated from my essence-Levinas states that "this absolution reverses essence" (50) into a disinterestedness. This disinterestedness is identity transformed: the reversion of the ego to a self, a reversion from the conscious and willing being to the passivity of the creaturely subject in substitution for the other. The subject here is not an abstraction that can be made adequate to a general category or equivalent to other subjects or objects subjected to universalization and reification. Stripped of the identity afforded it within the said, the subject is exposed, denuded as the singular and unique being substituted for the other.

Levinas writes that the reversion from the ego to the self takes the form of "a corporeal life devoted to expression and to giving. It is devoted, and does not devote itself: it is a self despite itself, in incarnation, where it is the very possibility of offering, suffering and trauma" (50). The 
modality of disinterestedness and the call to responsibility it answers are inescapable because they are irrevocably bound to incarnation. To live in and as a body is to be devoted, prior to any act of self-devotion, to giving to the other, and to substitution. The subject is utterly passive, beyond the passivity that would be opposed to activity, and passive prior to any contract (social or otherwise) entered into. It does not have a narrative of its own that centers and grounds it, providing it with a place from which to launch projects or in which to exercise free will. According to Levinas, "the subject... does not give signs, it becomes a sign, turns into an allegiance" (49). If the subject merely gave out signs, this would mean that it was at home with itself, self-identical, sheltered from vulnerability. But the subject in the ethical relation is not a for-itself. Subjectivity is an allegiance; subjectivity is a sign that signifies "I am for you."

In Otherwise than Being, Levinas conceives of the subject not as a thing, but fundamentally, as a creature - as that which has been created as uniquely singular. This singularity of the subject is incompatible with the totality as a universalizing force requiring the standardization and exchangeability of all human beings for one another in the liberal ideal of universality. The subject returns to this creaturely form in the moment that it is cast outside of the totality that would furnish its identity as a part of the whole, a derivation of the One. This moment of recoil is the unidentifiable and non-thematizable event of the call of the other. The most emphatic description of Levinas' sense of ethical subjectivity comes from Asher Horowitz, who writes in the Preface to his Ethics at a Standstill that the subject "is not only in this relation but also is this relation"(Horowitz $\mathrm{x}$ ). In other words, there is no subjectivity without the ethical relation that binds me in responsibility to the other, because subjectivity is not identity; it is the ethical bond itself.

The passivity of the subject is prior to the dualism that conceives being in terms of the split between nature and spirit, body and mind. Radical passivity is not the passivity of a spatio-temporal body, but rather the passivity of a created entity prior to its entry onto the ontological plane that separates the spiritual from the physical-prior to the conceptualization of spiritual and physical as separate spheres of experience and influence. "Popular materialism" ("Reflections" 8) is insufficient to the task of describing subjectivity and the ethical relation because "obsession is anarchical; it accuses me beneath the level of prime matter" (Otherwise than Being 110). My obsession with the other, my inability to leave the other alone with her suffering, cannot be located and worked through psychologically, because it accuses me of my insufficiency prior to my formation as a self-identical ego.

It is only through incarnation as compassion and as an exposure to suffering (my own and the suffering of others) that the self exists at all. The gift of subjectivity arises out of the suffering of the self and in answer 
to the suffering of the other. The freedom that arises in the creation of the subject as ethical relation is the freedom from one's immersion in the totality and freedom from the obsession with one's own biological suffering. The body exposes us to "the gift that costs" (195, note 12). What does this gift cost us but our very identity within the ontological order?

\section{The Universal and the Particular: Freedom Otherwise}

In the transformation of the philosophy of Hitlerism into a political program, blood becomes the pagan One into which the many are dissolved in anonymous participation. Personal responsibility devolves into personal devotion to the Volk. It is at this point, that we see the emergence of elemental evil clearly; as ego identity dissolves into a unified and undifferentiated whole, (be that whole defined in terms of nation, race, or state) - there is a significant reduction in personal responsibility. The deficit of real fraternity and community engendered by liberalism (although it is purportedly dedicated to the promotion of these ideals) is replaced by an all-encompassing allegiance to the Volk. The freedom guaranteed by this allegiance is the freedom from responsibility for and to others not of one's own race.

The new notion of community introduced by the philosophy of Hitlerism, delimited as it is by biology, needs signifying others: those who embody that which is not pure in contrast to the true race, and can, therefore, serve as scapegoat in the purification of the community. Interestingly, Levinas makes no overtures towards a theory of antiSemitism here, nor does he display any interest in roughly contemporary attempts to understand anti-Semitism in terms of Freudian theories of group psychology. ${ }^{10}$ Such theories do not correspond to Levinas' understanding, further developed in Otherwise than Being, of a primordial relation that opens upon both the possibility of murder and a potential ethical relation between self and other in which I am for the other. The follower of Nazism capitulates his or her abstract freedom and autonomy to a force beyond his or her control in order that he or she might paradoxically gain a measure of control over social relations in the material world. Liberalism had promised to deliver this control to the hands of the rational subject, but it always disappoints in this regard because it has not liberated the subject from the pagan logic of the many in the One. For Levinas, what is of paramount importance in the fascist will to power is its character as an escape from the demands of the other upon

${ }^{10} \mathrm{I}$ am thinking specifically here of "Elements of Anti-Semitism: Limits of Enlightenment" in Horkheimer and Adorno's Dialectic of Enlightenment. 
me. Liberalism represses this demand, but this repression is a mere evasion that leaves us even more vulnerable to fascism, given that it denies us the insight into the otherwise than being via the experience of our bodies.

In "Reflections on the Philosophy of Hitlerism," Levinas concerns himself with the ideological and spiritual dimensions of evil, which he recognizes as a force present within liberal philosophy as well as Nazi ideology. In the earlier essay, Levinas targets "the European notion of man," but later, in his dedication to Otherwise than Being or Beyond Essence to "the millions on millions of all confessions and all nations, victims of the same hatred of the other man, the same anti-semitism," he seems to extend this wasted potential for freedom beyond the specific context of European culture. Levinas suggests there that any attempt to understand eruptions of anti-Semitism as particular events within history risks evading the source of anti-Semitism itself: the fear of the other's claim on me that erupts into a violent embrace of sameness. This reticence on Levinas' part to preserve the specific social, political, ideological and economic roots of Nazi anti-Semitism might very well be seen as a weakness, ${ }^{11}$ but it is also a strength, in that it serves as an excellent explanation for the resiliency of pagan logic.

${ }^{11}$ A potentially troubling way in which Levinas himself falls short of his aims to counter the "European notion of man" surfaces when we turn to consider his remarks regarding non-European and non-Judaic cultures, particularly his disdain for and fear of African culture (expressed in an interview published in Raoul Mortley's French Philosophers in Conversation) and what Howard Caygill has argued is Levinas' refusal to see the Palestinian as the other. Taking Levinas to task for his reliance on the feminine in Totality and Infinity and his admission that although he refuses to see his claim that the Jews and the Greeks are the only human civilizations as a racist statement, Sonia Sikka agues: "this is a philosophy of the Other that, although it claims to be based on difference, is in another sense, indifferent to difference." She makes an important point that Levinas' philosophy, if it is viewed from the vantage point of the Western tradition - "male, European and Greco-Christian" (114)_looks like the interruption it claims to be. But outside of that tradition, Levinas' philosophy seems to have more in common with the European notion of man. These are important criticisms that I do not intend to sweep aside, but it occurs to me that they should be taken as appeals to read Levinas differently and productively to engage with the original impulse that motivates the philosophy itself, to rescue what we can of the most radical aspects of Levinas' philosophy of the ethical relation, and to return to the core of Levinas' philosophy - the otherwise than being positioned as a potential challenge to the totality of being - in order to reconfigure his philosophy as a philosophy of the Other that registers the pain and shock of difference without itself being allergic to it. Levinas' philosophy is difficult to come to terms with, because it is both a philosophy that upholds the value of singularity and a philosophy that attempts to propose an understanding of the human condition. As such, it both affirms and denies difference. I suggest that it is important to read it diachronically, understanding the universal human condition of substitution as that which makes possible a commitment to a philosophy of difference. 
Levinas concludes that Hitlerism (and racism in general) is not merely an isolated particularism that opposes itself to some aspects of Western culture. Hitlerism institutes itself as the force that will form a new world. The creation of this world will require a new conception of truth, radically opposed to the subjective truth subordinated to the free choice of a sovereign reason; "truth is no longer ... the contemplation of a foreign spectacle; instead it consists in a drama in which man is himself the actor" ("Reflections" 10). Within this drama, the individual is as bound to truth as she is to biological being. And the bind between individual, truth, and biology is a shared one - shared with, but limited to, all the other members of the society of consanguinity to which the individual belongs. Levinas observes that in order to guarantee the sincerity and authenticity this new conception of truth promises to deliver, it must be absolute - not merely "my truth" (10). In other words, it must have the character of a universal truth, but this will necessitate "a basic modification of the very idea of universality" (10).

The notion that Hitlerism could found a new world, that it sees itself capable of asserting a truth that could be conceived as absolute and universal seems illogical, even paradoxical. For how could the very particular case of a self-declared superior race become a universally acceptable ideology? Levinas maintains that in order for this situation to develop, "universality must give way to the idea of expansion" (10, emphasis in the original). No longer can the universal be thought of as an idea propagated in the spirit of liberal equalization that "creates a community of masters" (11). Chanter and Manning have both read Levinas' distinction between the liberal ideal of mastery through universalization and the fascist will to expansion as a partial acceptance of liberalism. But I argue that this destruction of "the community of masters" (11) is not, in itself, mourned by Levinas. Furthermore, the universalizing logic of liberalism itself makes possible this giving way. The notion of a community of masters is a problematic formulation, since, as an abstract and rational "community" of "peers" (11) it does not reflect the essentially asymmetrical relationship between self and other that he will address in his later works.

While liberalism represses difference and the asymmetrical ethical relation in its promotion of universality, the philosophy of Hitlerism replaces the force of this "community of masters" (11) with the expansive force of mastery in a particular form. Under the political rule of the National Socialists and within the philosophical logic of Hitlerism, universal agreement will be instituted by force-a force of expansion that upholds the masterful control of the so-called superior race over all others. Rather than the supposedly anonymous and neutral character of the universal idea within liberalism, the force of expansionism "is attached to the personality or society exerting it, enlarging that person or society while 
subordinating the rest" (11). The philosophy of Hitlerism's modification of the idea of universality is generally read as a break with Europe's liberal and Enlightened past, yet for Levinas, it reveals the legacy of the pagan logic of the many in the One that continues to exert its influence over this tradition. In the wake of the philosophy of Hitlerism, any attempt to attain the truth through the categorical rationality that subsumes particulars under the cover of a universal should be recognized with some suspicion.

The philosophy of Hiterlism offers a critique of the European tradition of liberalism and of "the European notion of man" that reveals the pagan logic at the heart of the problematic concept of universality. In forging a philosophy capable of countering both the European notion of man and the racist ideology that it facilitates, Levinas introduces us to an ethical relation that exits outside of this logic. Because time is diachronous, Levinas can claim that the time of being can correspond to the logic of the many in the One, while the subject in substitution for the other, the subject as sensibility, even though it is a fundamentally universal condition for all humanity, remains beyond this logic. In Otherwise than Being or Beyond Essence, Levinas writes: "To say that the ego is a substitution is then not to state the universality of a principle, the quiddity of an ego, but, quite the contrary, it is to restore to the soul its egoity which supports no generalization" (Otherwise than Being 127). The term "subject" when thought of as a substitution for the other undergoes a transformation that divorces it from any appeal to universality and restores singularity and unicity to the subject itself; "I am not another but me" (127). On this score, Levinas finds praise for "Modern antihumanism" because it has "abandoned the idea of person," which clears the way for "subjectivity positing itself in abnegation, in sacrifice, in a substitution which precedes the will" (127). My substitution for the other is prior to my constitution as a self-identical ego and is non-transferable; it is only "I" in my very unicity, who can take on the role of hostage for the other.

The philosophy of Hitlerism contains an undeniable truth: I am tied to my body. What is false in the philosophy of Hitlerism is the idea that this ties me to an exclusive people and a fated existence, because prior to this bondage of the self to the body I am bound to all the other others suffering and enjoying embodiment, not just those who supposedly share with me common blood. This is what Levinas means when he writes that the incarnate subject "is not a biological concept" (109). As a relational tie, the bond between self, body and other subjects me to change, alteration, transcendence. This alteration is not within my power, but it is within my responsibility to answer for its effects. This bond to all the others makes me responsible for all the others, beyond even my own direct influence upon them. In the time of fecundity explored in Totality and Infinity, it becomes apparent that this responsibility extends even beyond 
my own physical death. If the freedom I am granted through the ethical relation with the other is qualified by these bonds, I cannot declare myself to be absolutely free; this removes the subject from the plot of absolute freedom as it is constructed within liberal thought. Likewise, I cannot commit myself to a racist project without betraying my fundamental responsibility for the other, thereby negating the conditions of possibility for my own freedom.

In Otherwise than Being, Levinas argues that the (ersatz) freedom claimed by the liberal subject is predicated upon the freedom achieved through the transcendence of the same that occurs in the subject's response to the call of the other. In answering the call of the other, I am pulled out of the obsessive identification with my body as my object or my possession (Levinas obliquely references Heidegger's Jemeinigkeit here), and pulled into freedom. In other words, by calling me out, the other provides me with the necessary distance from what Heidegger calls Sorge - the care and concern for my own body, its finitude and mortality - so that I can think and act and give freely, without reserve. Levinas' theory of freedom does what liberalism cannot; it stands in resistance to the philosophy of Hitlerism. Unlike the freedom offered by the philosophy of Hitlerism, the freedom Levinas posits in Otherwise than Being is not freedom from responsibility found in the anonymity of pagan unification in the One, but freedom as myself in substitution for the other.

Levinas returns to the question of pardon (which we first encountered in "Reflections on the Philosophy of Hitlerism" and then again in Totality and Infinity,) in Otherwise than Being, wherein he repeats the claim that pardon must be a function of a relation, and supplements this formulation with the assertion that the relation itself is fundamentally, and will remain, asymmetrical. In other words, I cannot ask of my neighbour what I ask of myself; "I can pardon others in their alterity inasmuch as they are subsumed under the concept of the ego" (198, note 30). In this sense, it would seem that the pardon that redeems can only be dealt to me in my singularity, as the irreplaceable one who is responsible for the other to the point of substitution for her, but I can only deal pardon to others in their particularity. This is Levinas' attempt to place limits on my ability to command responsibility, to, in a sense, institute its asymmetricality in social institutions, in order to prevent the interpretation of the subject's infinite responsibility for the other as something that I, personally, can demand of the other, or something that I can legislate into existence.

As subjectivity as a substitution for the other passes into the logos, it is transformed into a generalizable concept: the subject as it appears within the time of being. According to Levinas, justice requires universality, because there must be "a comparison between incomparables" (16) in order that society can be organized in conformity 
with the Good. In the name of justice, "I universalize myself" (126). In doing so, I betray the otherwise than being and revert to the pagan logic of the many in the One. Although we may conceive of this movement between the time of being and the time of being as alternation, it is important to remember that these times are simultaneous with one another. This means that the vulnerability of the subject as substitution is maintained in diachrony, even though once the subject "identifies itself in the temporality of its essence" (49) it finds shelter from exposure within self-identity. Because time is doubled, the subject can be both vulnerable and sheltered at the same time, in different and divergent times. So Levinas' temporalized description of the entry into the logos and the entry of the third who demands justice, is, in fact, misleading. This means that these two modes of subjectivity cannot be separated.

In his attunement to the experience of our bodies, Levinas was able to perceive the diachrony of existence that allows for the simultaneous existence of being and the otherwise than being. By doing so, he was able to uncover an originating freedom that both animates and opposes the spirit of liberalism. But by remaining loyal to this diachrony, Levinas' philosophy seems to be limited to a descriptive task. Certainly, Levinas prioritizes subjectivity as substitution and sensibility as the ethical foundation of all manifestations of subjectivity, but there is little sense, in Levinas' philosophy itself, that we could mobilize the critical insights concerning the European notion of man that Levinas presents in "Reflections on the Philosophy of Hitlerism" as a social or political program. It would seem that, if my claim that this conception of humanity as embroiled within the pagan logic of the many in the One is, in fact, the motivation for Levinas' philosophical project as a whole, then Levinas himself did not fully succeed in this project. It falls to his readers, those who recognize the radical nature of the subject he presents, to find the resources in his philosophy and, perhaps, in the work of others (see Horowitz), that might assist us in carrying on this work.

\section{Works Cited}

ADORNO, T.W. and M. HORKHEIMER. Dialectic of Enlightenment. London/New York: Verso Press, 1997.

ALFORD, C. Fred. "Levinas and Political Theory." Political Theory 32.2 (2004): 146-171.

CAYGILL, Howard. Levinas and the Political. London: Routledge: 2002. 
CHANTER, Tina. "Neither Materialism nor Idealism: Levinas' Third Way." Postmodernism and the Holocaust. Eds. A. Milchman and A. Rosenberg. Amsterdam: Rodopi, 1998. 137-154.

DRABINSKI, John. Sensibility and Singularity: The Problem of Phenomenology in Levinas. Albany: State University of New York, 2001.

HEGEL, Phenomenology of Spirit. Trans. A.V. Miller. Oxford: Oxford University Press, 1977.

HEIDEGGER, Martin, Being and Time. Trans. J. Stambaugh. Albany: SUNY Press, 1996.

HERZOG, Annabel. "Is Liberalism "All we Need"? Levinas' Politics of Surplus.” Political Theory 30.2 (2002): 204-227.

HOROWITZ, Asher. Ethics at a Standstill: History and Subjectivity in Levinas and the Frankfurt School. Pittsburg: Duquesne University Press, 2008.

HOROWITZ, Gad and Asher HOROWITZ. "Is Liberalism All We Need? Prelude via Fascism." Difficult Justice: Commentaries on Levinas and Politics, Eds. G. Horowitz and A. Horowitz. Toronto: University of Toronto Press, 2006. 12-23.

KANT, Immanuel. The Moral Law: Kant's Groundwork of the Metaphysic of Morals. Trans. H.J. Paton. London: Hutchinson University Library, 1969.

LEVINAS, Emmanuel, On Escape. Trans. B. Bergo. Stanford: Stanford University Press, 2003.

—. Otherwise than Being or Beyond Essence. Trans. A. Lingis. Pittsburg: Duquesne University Press, 1981.

—. "Reflections on the Philosophy of Hitlerism" Trans. S. Hand, Difficult Justice: Commentaries on Levinas and Politics, Eds. G. Horowitz and A. Horowitz. Toronto: University of Toronto Press, 2006.3-11.

-. Theory of Intuition in Husserl's Phenomenology. Trans. A. Orianne. Evanston, Illinois: Northwestern University Press, 1995.

-. Totality and Infinity: An Essay on Exteriority. Trans. A. Lingis. Pittsburg: Duquesne University Press, 1969. 
MANNING, J.S. "Serious Ideas Rooted in Blood: Emanuel Levinas' Analysis of the Philosophy of Hitlerism." Postmodernism and the Holocaust, Eds. A. Milchman and A. Rosenberg. Amsterdam: Rodopi, 1998. 125-136.

MORTLEY, Raoul. French Philosophers in Conversation: Levinas, Schneider, Serres, Irigaray, Le Doeuff, Derrida. New York: Routledge, 1991.

SIKKA, Sonia. "The Delightful Other: Portraits of the Feminine in Kierkegaard, Nietzsche, and Levinas." Feminist Interpretations of Emmanuel Levinas, Ed. T. Chanter. Penn State Press, 2001.

TAHMASEBI-BIRGANI, Victoria. Emmanuel Levinas and the Politics of Non-Violence. Toronto: University of Toronto Press, 2014. 